\title{
Thiol/disulfide homeostasis in patients with chronic hepatitis B
}

\section{Kronik hepatit B hastalarında tiyol/disülfit dengesi}

\author{
Neslihan Çelik ${ }^{*}$ (D), Cemile Biçer ${ }^{2}$ (D), Onur Çelik ${ }^{3}$ (D), Ayşe Çarlıoğlu 4 (D), Murat Alışık ${ }^{5}$ \\ ${ }^{1}$ Infectious Diseases, Regional Training and Research Hospital, Erzurum, Turkey \\ ${ }^{2}$ Biochemistry, Yildirim Beyazit University, Ankara, Turkey \\ ${ }^{3}$ Pulmonology, Regional Training and Research Hospital, Erzurum, Turkey \\ ${ }^{4}$ Endocrinology, Regional Training and Research Hospital, Erzurum, Turkey \\ ${ }^{5}$ Biochemistry, Polatli State Hospital, Ankara, Turkey \\ * Corresponding author: Neslihan Çelik E-mail: drneslihancelik@yahoo.com.tr ORCID: 0000-0003-4543-9247 \\ Received: 9 October 2019 Accepted: 22 May 2020
}

\begin{abstract}
Aim: The purpose of this study was to evaluate the relation between chronic hepatitis $B(\mathrm{CHB})$ and the thiol/disulfide balance, used as a marker of oxidative stress.

Materials and Methods: This study was conducted between May 2016 and July 2016 at the Erzurum Regional Training and Research Hospital Infectious Diseases Polyclinic. 63 subjects with CHB and 60 healthy volunteers without any known diseases were included in the study. In term of measuring dynamic thiol/disulfide homeostasis, we used the novel automated assay method developed by Erel and Neselioglu.
\end{abstract}

Results: Native thiol (SH), total thiol (total $\mathrm{SH}$ ) and disulfide (SS) levels were determined; measures such as $\mathrm{SS} / \mathrm{SH}, \mathrm{SS} /$ total $\mathrm{SH}$, and $\mathrm{SH} /$ total SH were calculated. It is determined that CHB group's SH levels ( $\mathrm{P}=0.041)$, total SH levels $(\mathrm{P}=0.043)$ were lower than the control group's. There is negative correlation between Anti-HBc total lgG and total SH, SH, SH/total SH, there is positive correlation between Anti-HBc total $\mathrm{lgG}$ and SS/SH, SS/total SH ratio. There is negative correlation between BMX index and total $\mathrm{SH}, \mathrm{SH}, \mathrm{SH}$ /total $\mathrm{SH}$ and positive correlation between SS/total $\mathrm{SH}, \mathrm{SS} / \mathrm{SH}$. Positive correlation is determined between total protein, albumin and total $\mathrm{SH}, \mathrm{SH}$.

Conclusions: In our study thiol levels as an antioxidant were found to be low in CHB patients. Thiol levels were again emphasized as a new marker in hepatitis B. Thiol levels in $\mathrm{CHB}$ are thought to shed light to slowing of disease course and improving new treatment efforts with more wide studies.

Keywords: chronic hepatitis B, thiol/disulfide balance, oxidative stress

() 2020 by the authors; licensee MEDITAGEM Ltd., Turkey. This article is an open access article distributed under the terms and conditions of the Creative Commons Attribution License (http://creativecommons.org/licenses/by/4.0/). 


\section{öz}

Amaç: Bu çalışmanın amacı, oksidatif stres belirteci olarak kullanılan tiyol / disülfit dengesi ile kronik hepatit B (KHB) arasındaki ilişkiyi değerlendirmektir.

Gereç ve Yöntem: Bu çalışma Mayıs 2016 - Temmuz 2016 tarihleri arasında Erzurum Bölge Eğitim ve Araştırma Hastanesi Enfeksiyon Hastalıkları Polikliniğinde yapıldı. Çalışmaya KHB'li 63 hasta ve bilinen herhangi bir hastalığı olmayan 60 sağlıklı gönüllü dahil edildi. Dinamik tiyol /disülfit dengesini ölçmek için Erel ve Neselioğlu tarafından geliştirilen yeni otomatik analiz yöntemini kullanıldı. Doğal tiyolden (SH) sonra, toplam tiyol (toplam SH) ve disülfit (SS) seviyeleri belirlendi; SS/SH, SS/toplam SH ve SH/toplam SH gibi ölçüler hesaplandı.

Bulgular: KHB grubunda, SH seviyelerinin $(P=0,041)$, toplam $\mathrm{SH}$ seviyelerinin $(P=0,043)$ kontrol grubundan düşük olduğunu tespit edildi. Anti-HBc toplam IgG ile toplam SH, SH, SH/toplam SH arasında negatif korelasyon vardı, Anti-HBc toplam IgG ile SS/SH, SS/toplam SH oranı arasında pozitif korelasyon vardı. BMX indeksi ile toplam SH, SH, SH/toplam SH arasında negatif, SS/total SH, SS/SH arasında pozitif korelasyon vardı. Toplam protein, albümin ve toplam SH, SH arasında pozitif korelasyon bulundu.

Sonuç: Çalışmamızda KHB hastalarında antioksidan olarak tiyol düzeyleri düşük bulundu. Hepatit B'de tiyol düzeyinin yeni bir belirteç olduğu tekrar vurgulandı. Gelecekte yapılacak daha geniş çalışmalarla KHB'de tiyol düzeyleri hem hastalığın seyrinin yavaşlatılması hemde yeni tedavi geliştirme çabalarına ışık tutacağı düşünülmektedir.

Anahtar kelimeler: kronik hepatit B, tiyol/ disülfit dengesi, oksidatif stres

\section{INTRODUCTION}

Hepatitis B infection is common in our country and in the world and is the leading infection among viral infections that become chronic [1]. In the pathogenesis of chronic viral hepatitis, oxidative stress and immunological damage resulting from direct cytotoxicity of some virus-derived substances are implicated. The liver is one of the most protected organs from the damage caused by oxygen radicals thanks to its various repair mechanisms and protective enzymes as well as some antioxidants it contains. Nonetheless, fibrosis, which develops due to the prolonged inflammatory reaction and subsequently increased collagen synthesis, may result in liver cirrhosis, especially in viral hepatitis. It is generally accepted that free oxygen radicals are involved in the pathophysiology of liver diseases and lead to the progression of the disease [2].

Also, oxidative stress can be simply described as an imbalance between the antioxidant defense of the body and free radical production [3]. Free oxygen radicals lead to disorders in membrane structure and cellular functions by means of denaturation of proteins, damage to nucleic acids, and lipid peroxidation, and play a role in the pathogenesis of many diseases [4]. Free oxygen radicals are influential in reactions caused by various drugs/toxins such as lead poisoning (toxicity), carbon tetrachloride-induced hepatic damage, and in glomerulonephritis, hepatitis $B$, ischemia, vitamin ( $C$ and $E$ ) deficiency, and in the pathogenesis of many diseases such as cancer, emphysema, hyper oxidation, bronchopulmonary dysplasia, atherosclerosis, pancreatitis and rheumatoid arthritis [3]. Antioxidants trying to prevent the damaging effects of free radicals, especially thiol groups, cannot preserve the plasma and tissue levels during these affections [5]. Thiols are a class of organic compounds that contain a sulfhydryl group (-SH) which is composed of a hydrogen and a sulfur atom attached to a carbon atom [6]. And they are compose the basic part of the nonenzymatic antioxidant system in the circulation, and are the first molecules responsible for neutralization of oxidant molecules [7]. Among the antioxidants found in plasma, the highest concentration of thiol groups is explained by the high plasma protein levels in adults. Because the primary source of thiol groups found in plasma are cysteine and methionine amino acids in protein structures, especially albumin, as well as reduced glutathione (GSH). The determination of plasma thiol levels is important as it shows how the proteins are affected by SOR-mediated oxidation [8]. While the serum thiol/disulfide levels were previously assessed indirectly, direct measurement possibility has been available with fully-automated calorimetric technique which was found by Erel and Neselioglu in 2014 [9].

The purpose of this study was to evaluate the relation between $\mathrm{CHB}$ and the thiol/disulfide balance, used as a marker of oxidative stress, by measuring that exchange 
using a novel technique. This study is important as the first, to the best of our knowledge, involving this novel biomarker, previously used in the investigation of different diseases.

\section{METHOD}

This study was conducted between May 2016 and July2016 at the Erzurum Regional Training and Research Hospital Infectious Diseases Polyclinic.

The study population included a total of 123 participants; 63 hepatitis B ( 28 women and 35 men) patients, and 60 healthy volunteers ( 25 women and 35 men) with no historyof chronic illness or regular drug use.

The study was conducted in accordance with the Declaration of Helsinki 2013 Brasil version and was approved by the Erzurum Regional Training and Research Hospital Ethics Research Committee (2016/9-62). All subjects were provided written informed consent prior to participation in the study.

The patients enrolled in the study was clinically and serologically diagnosed as chronic hepatitis B after 6 months follow up. Blood sample was taken in their routine polyclinical control. Control group was selected from patients referred to our polyclinic with a diagnosis of other than hepatitis B. The patients which were under systemic steroid treatment and with cerebrovascular disease, chronic and acute kidney disease, additional liver disease, acute and chronic systemic disease like malignancy and the patients regularly using antioxidant, antilipid, vitamin drugs, smokers, alcoholics were excluded from the study.

After blood sample was taken, plasma and serum were separated by centrifuging at $1500 \mathrm{rpm}$ for ten seconds. Serum was kept in $-80^{\circ} \mathrm{C}$ in Eppendorf tubes until they were tested. Afterwards thiol hemostasis parameters were studied from the same blood sample. Patients' synchronous whole blood count biochemical parameters including cholesterols and hepatitis markers, HBV- DNA levels were recorded.

In term of measuring dynamic thiol/disulfide homeostasis, we used the novel automated assay method developed by Erel and Neselioglu, in which both sides of thiol/disulfide balance can be measured as opposed to the method developed by Ellman, which can measure only one side of this balance. This novel method is based on the sulfhydryl groups of proteins turning into a reversible formation of disulfides under oxidative conditions and reduction of disulfide bonds into thiol groups again. The difference between the total thiol and the native thiol is divided by two to obtain the amount of the disulfide bond. Measurements were made using a Cobasc501 (Roche Diagnostics, Mannheim, Germany). Serum thiol/disulfide homeostasis values were presented as $\mathrm{mmol} / \mathrm{L}[10]$.

From the obtained data, total thiol, native thiol, disulfide, disulfide/total thiol, disulfide/native thiol, native thiol/total thiol levels were determined. Results were compared between CHB patients and healthy subjects.

Total protein (TP), albumin, alanine aminotransferase (ALT), aspartate aminotransferase (AST), gamma glutamyl transferase (GGT), alkaline phosphatase (ALP) was measured with the Abbott Architect c16000 (USA) autoanalyzer. All $\mathrm{CBC}$ analysis was performed in the hematology laboratory of our hospital with the use of a Abbott Cell-Dyn Ruby (USA) autoanalyzer. Hepatitis $B$ markers were performed by Abbott (architect) i2000sr, HBV-DNA RT PCR Rotorgene (Giasymphny) autoanalyzer. All parameters were compared with thiol/disulphide homeostasis. Correlation of whole obtained parameters with thiol/disulfide homeostasis were analyzed.

\section{STATISTICAL ANALYSES}

We performed all statistical analyses using SPSS for Windows, version 17.0. Unless otherwise stated, results wereexpressed as mean $\pm \mathrm{SD}$. We used the Mann-Whitney $\mathrm{U}$ test or independent sample $t$ test between two subject groups, and used the Pearson correlation test or Spearman correlation test, as appropriate. Categorical data were analyzed by Chi-square test. The receiver operating characteristic (ROC) curve analysis assessed the cut-off thiol levels the best diagnostic accuracy for detecting differentiated $\mathrm{CHB}$.

\section{RESULTS}

In this cross-sectional study, 63 patients with chronic hepatitis $B$, and 60 control subjects were evaluated. Mean age \pm SD of subjects were $41.2 \pm 13.4$ in the hepatitis group and $34.9 \pm 13.8$ in the control group $(p<0.01)$.

There was negative correlation between age and $\mathrm{SH}$, $\mathrm{SH} /$ total $\mathrm{SH}$; positive correlation between age and $\mathrm{SS} / \mathrm{SH}$, $\mathrm{SS} /$ total SH. There is no statistical significance between age, sex and thiol levels.

SH levels ( $366 \pm 66 \mu \mathrm{mol} / \mathrm{L}, 392 \pm 72 p=0.041$ ), total SH levels $(439 \pm 80,470 \pm 80 \mathrm{p}=0.043)$ of patients with CHB significantly lower than control subjects (Figure 1). All parameters compared between two group were presented (Table 1). 

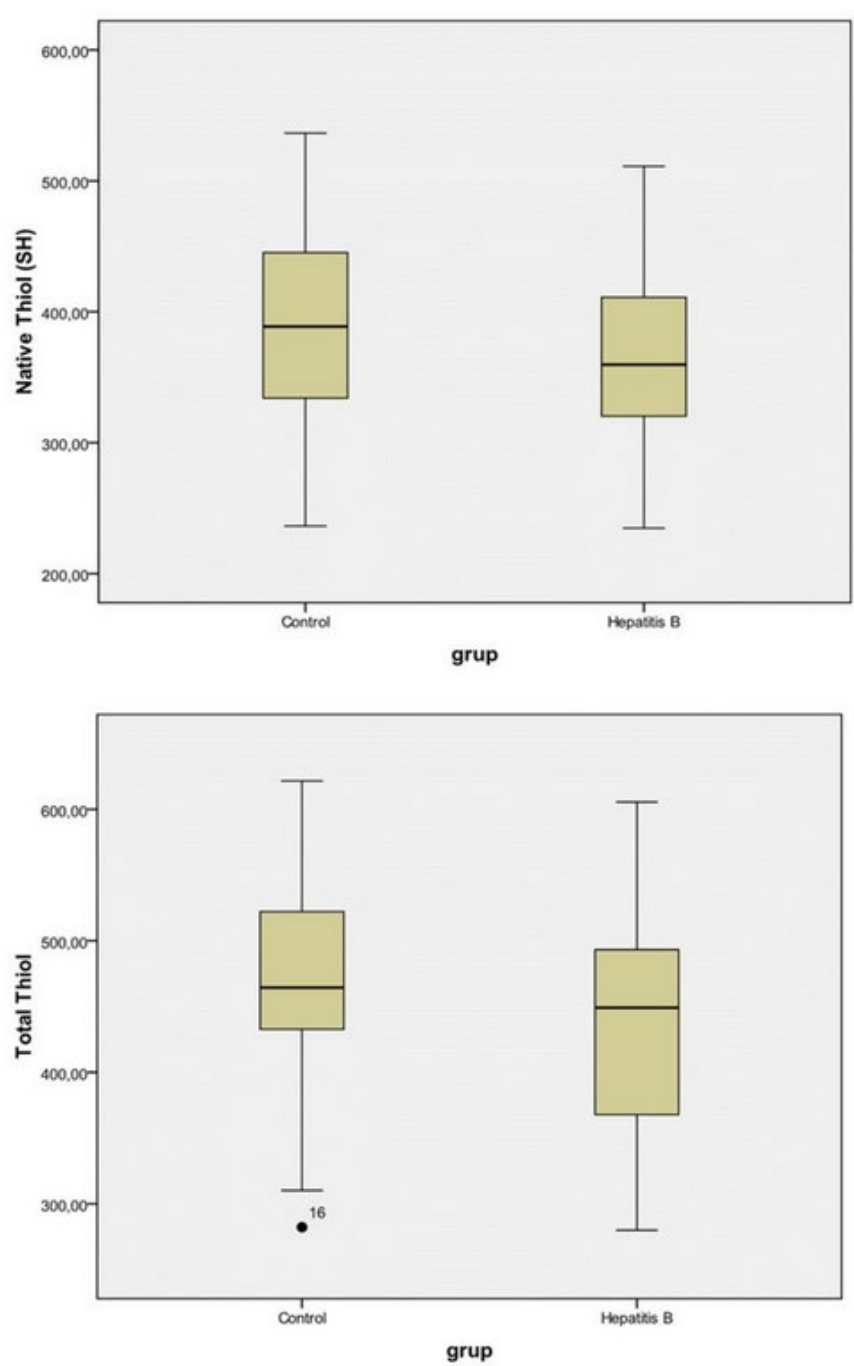

Figure 1. Thiol/disulfide homeostasis according to groups. Native thiol and total thiol level between groups.

Negative correlation between AntiHBc total IgG and total $\mathrm{SH}, \mathrm{SH}, \mathrm{SH} /$ total, $\mathrm{SH}$; positive correlation between AntiHBC total $\operatorname{lgG}$ and $\mathrm{SS} / \mathrm{SH}, \mathrm{SS} /$ total $\mathrm{SH}$ were determined.

Negative correlation between $\mathrm{BMX}$ index and total $\mathrm{SH}, \mathrm{SH}$, $\mathrm{SH} /$ total $\mathrm{SH}$ was found. Also, there was positive correlation between $\mathrm{BMX}$ index and SS/total SH, SS/SH.

There is positive correlation between albumin and total $\mathrm{SH}$, $\mathrm{SH}$ and positive correlation between total protein and total $\mathrm{SH}, \mathrm{SH}$.

Furthermore, High disulfide levels and low thiol levels in patients with $\mathrm{CHB}$ were found to be independent of sex, HBVDNA, HBsAg, antiHBs, AFP, ALP, GGT, AST, ALT, neutrophil and thrombocyte count (Table 2).

\section{DISCUSSION}

HBV infection is clinically observed in the form of acute infection, chronic infection or primary hepatocellular carcinoma (PHC). While chronic hepatitis is seen in $5-10 \%$ of
Table 1. Demographics and laboratory findings of study population

\begin{tabular}{|c|c|c|c|}
\hline & $\begin{array}{l}\text { Control } \\
n(60)\end{array}$ & \begin{tabular}{|c|} 
Chronic hepatitis B \\
$n(63)$
\end{tabular} & p value \\
\hline Sex (male), $n$ & $60(35)$ & $63(35)$ & 0,75 \\
\hline Age (years) & $34.91 \pm 13.87$ & $41.21 \pm 13.40$ & $0.01^{*}$ \\
\hline BMI $\left(\mathrm{kg} / \mathrm{m}^{2}\right)$ & $26.61 \pm 3.97$ & $27.10 \pm 3.26$ & 0.45 \\
\hline Total thiol $(\mu \mathrm{mol} / \mathrm{L})$ & $470 \pm 80$ & $439 \pm 80$ & $0.043^{*}$ \\
\hline Native thiol ( $\mu \mathrm{mol} / \mathrm{L})$ & $392 \pm 72$ & $366 \pm 66$ & $0.041^{*}$ \\
\hline$\% S H / T o t a l ~ S H$ & $83.69 \pm 7$ & $83.66 \pm 6.7$ & 0.092 \\
\hline $\mathrm{SS}(\mu \mathrm{mol} / \mathrm{L})$ & $38.67 \pm 18$ & $36.64 \pm 17.27$ & 0.541 \\
\hline SS/SH ratio (\%) & $10.17 \pm 5$ & $10.16 \pm 5$ & 0.996 \\
\hline$\% \mathrm{SS} /$ Total SH & $8.1 \pm 3.5$ & $8.1 \pm 3.3$ & 0.983 \\
\hline WBC $\left(10^{3} / \mu \mathrm{L}\right)$ & $7758.33 \pm 1793.42$ & $7233.33 \pm 1849.20$ & 0.107 \\
\hline Platelet & $259.88 \pm 55$ & $273.91 \pm 85$ & 0.53 \\
\hline HBV-DNA & & $903275 \pm 4.1$ & $0.000^{*}$ \\
\hline $\operatorname{ALT}(\mathrm{U} / \mathrm{L})$ & $20.90 \pm 10.19$ & $27.63 \pm 23.20$ & $0.000^{*}$ \\
\hline AST (U/L) & $20.22 \pm 9.04$ & $23.85 \pm 12.45$ & $0.02^{*}$ \\
\hline GGT (U/L) & $73.45 \pm 22.70$ & $21.19 \pm 16.78$ & $0.000^{*}$ \\
\hline Albumin (g/dL) & $4.36 \pm 0.45$ & $4.31 \pm 0.40$ & 0.26 \\
\hline AFP & $2.2 \pm 1.02$ & $2.65 \pm 1.96$ & 0.63 \\
\hline $\mathrm{TP}(\mathrm{g} / \mathrm{dL})$ & $7.02 \pm 0.40$ & $7.06 \pm 0.81$ & 0.09 \\
\hline ALP & $25.26 \pm 37.16$ & $88.40 \pm 39.75$ & $0.000^{*}$ \\
\hline
\end{tabular}

BMI body mass index, SS disulfide, SH native thiol, Total SH total thiol, WBC white blood cell, ALT alanine aminotransferase, AST aspartate aminotransferase, GGT gamma glutamyl transferase, TP total protein, ALP alkaline phosphatase, AFP alfa feto protein, HBV-DNA hepatitis $B$ virus deoxy nucleic acid.

${ }^{*} p<0.05$ for chronic hepatitis B patients compared with controls

patients, cirrhosis and hepatic failure may also develop in $10 \%$ of those with chronic hepatitis. $80 \%$ of cases with PHC are associated with chronic HBV infection [11]. Oxidative stress causes various parenchymal injuries ranging from subclinical unicteric hepatitis to necroinflammatory hepatitis (acute, recurrent or chronic), cirrhosis and cancer [12].

In the course of viral hepatitis, it is suggested that reactive oxygen types released by the Kupffer cells and other active macrophages in the inflammatory zone cause peroxidation in cell membrane lipids, resulting in aldehyde products which directly activate stellate (ito) cells to transform into myofibroblasts and as a result of this, an increase in collagen synthesis and fibrosis develop [13]. It has been found that hepatitis B virus causes the release of pro-oxidant cytokines such as reactive oxygen types and tumor necrosis factor alpha (TNF- $a$ ) by activating phagocytic cells, and the inhibition of anti-oxidant enzymes such as superoxide 
Table 2. Bivariate correlation between thiol/disulphide homeostasis parameters and other variables in chronic hepatitis B

\begin{tabular}{|c|c|c|c|c|c|c|c|c|c|c|c|c|}
\hline \multirow[t]{2}{*}{ Variables } & \multicolumn{2}{|c|}{ Native thiol } & \multicolumn{2}{|c|}{ Total thiol } & \multicolumn{2}{|c|}{ Disulfide } & \multicolumn{2}{|c|}{$\begin{array}{c}\text { Disulfide/native } \\
\text { thiol }\end{array}$} & \multicolumn{2}{|c|}{ Disulfide/total thiol } & \multicolumn{2}{|c|}{$\begin{array}{c}\text { Native thiol/total } \\
\text { thiol }\end{array}$} \\
\hline & $r$ & $\mathbf{p}$ & $r$ & $\mathbf{p}$ & $r$ & $\mathbf{p}$ & $\mathbf{r}$ & $\mathbf{p}$ & $r$ & $\mathbf{p}$ & $\mathbf{r}$ & $\mathbf{p}$ \\
\hline Age & -0.305 & 0.004 & -0.24 & 0.23 & 0.114 & 0.299 & $242^{*}$ & .024 & $.238^{*}$ & .026 & $-.238^{*}$ & .026 \\
\hline Sex & .150 & .165 & .200 & .063 & .142 & .189 & .090 & .408 & .087 & .421 & -.087 & .422 \\
\hline BMi & $-.317^{* *}$ & .003 & $-.242^{*}$ & .025 & .143 & .191 & $.221^{*}$ & .042 & $.237^{*}$ & .029 & -.237 & .029 \\
\hline HBV-DNA & .217 & .210 & .203 & .243 & .043 & .808 & -.045 & .799 & -.029 & .871 & .029 & .870 \\
\hline Anti-HB total lg & $-.348^{* *}$ & .001 & -.249 & .022 & .195 & .076 & $.289^{* *}$ & .008 & $.285^{* *}$ & .009 & $-.285^{* *}$ & .009 \\
\hline $\mathrm{HBsAg}$ & -0.17 & 0.056 & -0.179 & 0.052 & -0.06 & 0.48 & -0.01 & 0.87 & -0.12 & 0.9 & 0.01 & 0.9 \\
\hline HbeAg & 0.155 & 0.09 & 0.13 & 0.14 & 0.04 & 0.61 & -0.006 & 0.95 & -0.006 & 0.95 & 0.006 & 0.95 \\
\hline AntiHBs & .122 & .265 & .111 & .312 & .044 & .688 & -.032 & .770 & -.015 & .890 & .015 & .891 \\
\hline Albumin & $.766^{* * *}$ & .000 & $.809^{* *}$ & .000 & .202 & .061 & -.061 & .574 & -.054 & .620 & .054 & .619 \\
\hline $\mathrm{TP}$ & .239 & .012 & .246 & .010 & .109 & .258 & .044 & .653 & .043 & .654 & -.043 & .655 \\
\hline AFP & .009 & .942 & -.008 & .946 & -.040 & .738 & -.047 & .696 & -.038 & .754 & .038 & .754 \\
\hline GGT & .158 & .094 & .151 & .108 & .079 & .406 & .036 & .706 & .035 & .708 & -.035 & .710 \\
\hline ALT & -.037 & .703 & -.010 & .920 & .085 & .374 & .074 & .437 & .075 & .435 & -.075 & .436 \\
\hline AST & -.021 & .825 & .001 & .993 & .039 & .679 & .035 & .710 & .035 & .704 & -.035 & .709 \\
\hline PLT & -.027 & .769 & -.037 & .687 & -.081 & .384 & -.085 & .358 & -.086 & .355 & .086 & .356 \\
\hline $\mathrm{BK}$ & .080 & .393 & .107 & .252 & .111 & .234 & .079 & .397 & .078 & .401 & -.079 & .400 \\
\hline
\end{tabular}

$\mathrm{p}<0.05$ was accepted as statistically significant

dismutase (SOD) by affecting the pro-oxidant and antioxidant balance in the host cell [14].

In recent years, many studies on oxidative stress in chronic viral hepatitis $(\mathrm{CVH})$ have been conducted [3].

A study of Halliwell et al. have indicated that lipid peroxidation may increase in relation to the inflammatory response in viral infections and that the earliest sign of reduced oxidative stress during recovery was an increase in antioxidant level [15]. In another study, Dikici et al. have found that the levels of oxidative enzymes were significantly increased and the levels of antioxidant substances were reduced in patients with acute and chronic viral hepatitis, and have demonstrated that the antioxidant level increased after interferon treatment [16].

The goal in the treatment of $\mathrm{CVH}$ is to suppress viral replication, to eliminate or halt cell damage by inhibiting the inflammatory response. The purpose of finding new originating points in the treatment search in order to increase antioxidant response has recently made the antioxidants more important [3]. Duygu et al. have shown that total antioxidant capacity reduced in proportion to the severity of the disease in chronic hepatitis B patients [17]. Bolukbas et al. have shown that oxidative stress was significant in patient groups, who are in the different periods of chronic hepatitis B infection, compared to the control group [18]. Again in another study, Yamamoto et al. have suggested that high oxidative stress accompanied necroinflammation in $\mathrm{CVH}$, cirrhosis, and hepatocellular carcinoma cases [19]. In order to prevent the damage of free radicals, there are defense systems called antioxidants in the body [20].

Thiol group compounds are organic substances that have an important role in defense against oxidative stress with their reductive characteristics. The major thiols found in the plasma are low-molecular-weight thiols including albumin thiols, protein thiols and cysteine, cysteinylglycine, glutathione, homocysteine, and Y-glutamyl cysteine. Oxidative products that form in the organism, such as reactive oxygen types, are reduced by transferring their excess electrons to the compounds containing thiol, and thiol groups are oxidized. The oxidation of thiol groups causes disulfide bonds to form. However, this is a reversible reaction and the resulting disulfide bonds can be reduced to thiol groups again. Thus, dynamic thiol-disulfide homeostasis is obtained. Dynamic thiol-disulfide homeostasis plays a critical role in antioxidant defense, detoxification, apoptosis, regulation of enzymatic activity, and cellular signal transduction [21]. In cases where the neutralizing capacity of antioxidant mechanisms to neutralize the oxidizing agents is not sufficient, damage to the cell membrane, lipids, nucleic acids, proteins, and extracellular matrix components may occur [22,23]. Therefore, when thiol/ disulfide homeostasis shifts towards the disulfide formation, these vital activities are adversely affected and pathologies occur in the structure and functions of many organs [24]. There is also a growing body of evidence demonstrating that an abnormal thiol/ disulfide homeostasis state is involved in the pathogenesis of a variety of diseases, including diabetes, cardiovascular disease, cancer, rheumatoid arthritis, chronic kidney disease, 
acquired immunodeficiency syndrome (AIDS), Parkinson's disease, Alzheimer's disease, Friedreich's ataxia (FRDA), multiple sclerosis and amyotrophiclateral sclerosis and liver disorder [3].

By measuring the dynamic thiol-disulfide homeostasis, information on many normal or abnormal biochemical processes can be obtained [21].

The Erel technique that we used in our study is a new system that reveals the total antioxidant response by simultaneously determining the oxidant and antioxidant capacity. Compared to other systems available today, the major advantages of this system is that it is reliable and sensitive, cheap and simple, completely easy and provides automatic measurement and is not affected by serum content such as bilirubin, serum lipids and anticoagulants [25].

its usefulness as a novel and sensitive oxidative stress mediator has been investigated in various diseases [26] However, this study is the first to assess dynamic thioldisulfide homeostasis in patients with CHB in the literature. In this respect, this study is very important. We found that in CHB group $(366 \pm 66 \mu \mathrm{mol} / \mathrm{L}, 392 \pm 72 \mathrm{p}=0.041)$, total SH levels $(439 \pm 80,470 \pm 80 p=0.043)$ were lower than the control group.

In a recent study, including patients with pre-diabetes, Ates et al. showed a positive correlation between disulfide and blood glucose concentrations [27]. In a study, including patients with newly diagnosed primary hypertension, there was a positive correlation between disulfide levels and blood pressure. Disulfide was identified as an independent risk factor for hypertension in this study [28]. In another study, an increase was found in a disulfide/thiol ratio in patients with idiopathic recurrent pregnancy loss; however, there was no difference in the disulfide levels [29]. Özşahin et al it is known that excessive production of free oxygen radicals by active neutrophils cause tissue damage. It was shown that both chronic renal failure (CRF) and hemodialysis (HD) patients' circulating neutrophils had a increased oxidative metabolism. Also in Özşahin et al's study it is found that plasma total thiol levels were less when compared with healthy individuals [8]. In other study CRF and CRF+diabetes mellitus (DM) patients' total and free thiol levels informing about antioxidant status were significantly low when compared with control group [21]. Matteuchi E et al. have reported that impairment of thiol redox homeostasis is an important factor in the development of DM and DM-related complications [30]. Mahmut et al.'s study shows that mechanism involving oxidative stress operates in the development of tip 2 diabetes [31]. Kundi et al. demonstrated that thiol levels correlated with the severity of coronary atherosclerosis and the mortality rate was higher in the group with low thiol levels (32). Furthermore, thiol levels were shown to be markedly reduced in patients with migraine [33]. In a study carried out by Erkus et al., a connection between low plasma thiol levels and left ventricular diastolic dysfunction was reported. The authors suggested that increased thiol levels could play a protective role in diastolic dysfunction [34].

In this study, there was no correlation between HBV-DNA level and thiol/disulfide homeostatic. Although there are several studies investigating the correlation between viral load and biochemical markers of hepatitis, there is a small number of studies describing the correlation between viral load and free radical damage in the literature. Kaya et al. have shown that there was a significant increase in malondialdehyde (MDA) levels, an indication of lipid peroxidation (LPO), but there was no correlation between viral load and MDA (an LPO product) and antioxidant enzyme activities [35]. Similarly, Wang et al. have found no correlation between HBV DNA and MDA levels [36].

The main limitation of our study is that it is a cross-sectional study. Age may also be a confounder factor. Because the age ranges of $\mathrm{CHB}$ (chronic hepatitis) patients and control group were compatible in our study. There was a positive correlation between age and $\mathrm{SH}, \mathrm{SH} /$ total $\mathrm{SH}$, and SS/SH and $\mathrm{SS} /$ total SH. In a study of Mahmut et al., a significantly negative correlation was determined between the SH level and the total SH level and the age. Researchers have previously shown that oxidative stress levels increased with age [31].

In chronic liver diseases, albumin level decreases and gamma-globulin increases due to necroinflammation and fibrosis [37]. In our study, there was also a positive correlation between albumin and total protein and total $\mathrm{SH}$, $\mathrm{SH}$. Due to the association of albumin with antioxidant capacity, it has been once again verified that it is a valuable parameter in the follow-up of patients with CHB.

The most sensitive indicator showing the encounter of an individual with hepatitis $B$ virus (HBV) is the presence of hepatitis $B$ core antibody (anti-HBc) response [38]. In our study, there was a negative correlation between AntiHBc total Ig G and total $\mathrm{SH}, \mathrm{SH}, \mathrm{SH} /$ total $\mathrm{SH}$, and a positive correlation between $\mathrm{SS} / \mathrm{SH}, \mathrm{SS} /$ total $\mathrm{SH}$. No correlation was found between $\mathrm{HBs} \mathrm{Ag}$ and thiol/disulfide balance. Anti-HBc total $\lg G(+)$ was found to be significant in the antioxidant capacity that we detected in all patients. It has been once 
again emphasized that the effects of oxidative stress should be monitored in all individuals who have experienced hepatitis $B$ virus.

There was a negative correlation between BMX index and total $\mathrm{SH}$ and $\mathrm{SH}, \mathrm{SH} /$ total $\mathrm{SH}$, and a positive correlation between SS/total SH and SS/SH.

Oxidative stress that is not excessive but persistent in chronic viral hepatitis causes mutations by affecting the host cell DNA, stimulates the fibroblastic activity and after a long period of time, complications such as cirrhosis and HSC occur. At the same time, reduced antioxidant capacity may result in exacerbation of the disease and fibrosis in chronic cases [13].

This study examined the thiol/disulfide balance in patients with CHB using a newly developed technique. To the best of our knowledge, this is the first study evaluated the oxidative stress using this marker in CHB.

With this study, it was considered that low thiol levels detected in patients with $\mathrm{CHB}$ will be suggestive in terms of ways to increase antioxidant capacity in the search for new treatments. Also, in the future, understanding how host cell DNA sets up the repair pathways in response to oxidative stress due to hepatitis $B$ virus effects will be indicative and invaluable in preventing chronic liver diseases and developing new treatment modalities. Furthermore, the significant correlation between AntiHBc total Ig G (+) and thiol/disulfide hemostasis in our study may be considered to be significant in terms of showing the presence of oxidative stress on isolated AntiHBc total lg $G(+)$ patient groups once again.

\section{DECLARATION OF CONFLICT OF INTEREST}

The authors received no financial support for the research and/or authorship of this article. There is no conflict of interest.

\section{REFERENCES}

1. Lai CL, Ratziu V, Yuen MF, Poynard T. Viral hepatitis B. Lancet 2003; 362: 2089-94. (doi: 10.1016/S01406736(03)15108-2).

2. Dede $F$, Köş $M$, Bukan N, Şener D, Demir M, Aydın Ö, Arhan M, Eskioğlu E. The Evaluation of Oxidative Stress Parameters in Chronic Viral Hepatitis. Istanbul Tıp DergIstanbul Med J 2011;12(4):175-80. (doi: 10.5505/1304.8503.2011.28199).
3. Sırmatel F, Duygu F, Çelik H, Selek Ş, Sırmatel Ö, Gürsoy B, Eriş FN. Evaluation of Total Oxidative Level and Total Antioxidant Capacity in Cases with Chronic Viral Hepatitis. Klimik Dergisi 2009; 22(3): 92-6.

4. Sabitha KE, Shyamaladevi CS. Oxidant and antioxidant activity changes in patients with oral cancer and treated with radiotherapy. Oral Oncol. 1999; 35(3): 273-7. (doi: 10.1016/S1368-8375(98)00115-8).

5. McCord JM. Human disease, free radicals, and the oxidant /antioxidant balance. Clin Biochem 1993; 25: 354-7. (doi: 10.1016/0009-9120(93)90111-I).

6. Kundi $\mathrm{H}$, Ates I, Kiziltunc E, Cetin M, Cicekcioglu H, et al. A Novel Oxidative Stress Marker In Acute Myocardial Infarction; Thiol/Disulphide Homeostasis, American Journal of Emergency Medicine. 2015; 33: 11. (doi: 10.1016/j.ajem.2015.06.016).

7. Guner R, Tasyaran MA, Keske S, Hasanoglu I, Kalem AK, Yapar D, et al. Relationship between total thiol status and thrombocytopenia in patients with Crimean-Congo hemorrhagic fever. Southeast Asian J Trop Med Public Health. 2012; 43: 1411-8.

8. Özşahin $A E$, Yazıcı C, Köse K, Utaş C, Tokgöz B. Malondialdehyde and Thiol Levels in Plasma of Hemodialysis Patients. Erciyes Üniversitesi Sağlık Bilimleri Dergisi (E.Ü. Journal of Health Sciences) 2004; 13(2): 8-14.

9. Erel O, Neselioglu S. A novel and automated assay for thiol/disulphide homeostasis. Clin Biochem 2014; 47: 326-32. (doi: 10.1016/j.clinbiochem.2014.09.026).

10. Gormez VA, Orengul C, Ozer FÖ, Uzuner S, Selek S. Thiol/Disulphide Homeostasis and Oxidative Stress Parameters in Children and Adolescents with Attention Deficit/ Hyperactivity Disorder. Anadolu Kliniği, Eylül 2016; 3: 12.

11. Robinson WS. Hepatitis $B$ virus and hepatitis D virus. In: Mandell GL, Bennett JE, Dolin R.eds. Mandell, Douglas and Bennett's Principles and Practice of Infectious Diseases. 5th ed. Philedelphia Pennnsylvania, Churchill Livingstone 2005; 1652-85.

12. Stehbens WE. Oxidative stres in viral hepatitis and AIDS. Experimental and Molecular Pathology 2004; 77: 121-32. (doi: 10.1016/j.yexmp.2004.04.007). 
13. Acar A, Görenek L, Aydın A, Eyigün PC, Eken A,Sayal A, Pahsa $A$. Investigation of oxidative stress and antioxidant defense in patients with hepatitis $B$ virus infection and the effect of interferon-plus lamivudin combination therapy on oxidative stres. Mikrobiyol Bul. 2009; 43: 41123.

14. Schwarz KB. Oxidative stress during viral infection: a review. Free Radic Biol Med. 1996; 21: 641-9. (doi: 10.1016/0891-5849(96)00131-1).

15. Halliwell B, Aruoma OI. DNA damage by oxygen-derived species. Its mechanism and measurement in mammalian systems. FEBS Lett. 1991; 281(1-2): 9-19. (doi: 10.1016/0014-5793(91)80347-6).

16. Dikici I, Mehmetoglu I, Dikici N, Bitirgen M, Kurban S. Investigation of oxidative stress and some antioxidants in patients with acute and chronic viral hepatitis B and the effect of interferon-alpha treatment. Clin Biochem. 2005; 38(12): 1141-4. (doi: 10.1016/j.clinbiochem.2005. 10.006).

17. Duygu F, Karsen H, Aksoy N, Taskin A. Relationship of oxidative stress in hepatitis $B$ infection activity with HBV DNA and fibrosis. Ann Lab Med. 2012; 32(2): 113-8. (doi: 10.3343/alm.2012.32.2.113).

18. Bolukbas C, Bolukbas FF, Horoz M, Aslan M, Celik H, Erel $O$. Increased oxidative stress associated with the severity of the liver disease in various forms of hepatitis $B$ virus infection. BMC Infect Dis. 2005; 5: 95. (doi: 10.1186/14712334-5-95).

19. Yamamoto Y, Yamashita S, Fujisawa A, Kokura S, Yoshikawa T. Oxidative stress in patients with hepatitis, cirrhosis, and hepatoma evaluated by plasma antioxidants. Biochem Biophys Res Commun. 1998; 247(1): 166-70. (doi: 10.1006/bbrc.1998.8752).

20. Gutteridge JM. Lipid peroxidation and antioxidants as biomarkers of tissue damage. Clin Chem. 1995; 41: 181928. (doi: 10.1093/clinchem/41.12.1819).

21. Coşkun C, Emre HÖ, Gümüş A, Uzun S, et al. Dynamic Thiol Disulphide Homeostasis and Advanced Oxidation Protein Products (Aopps) in Diabetic and Non-Diabetic Chronic Renal Failure Disease. Deneysel Tıp Dergisi 2016; 6(12).

22. Kloner RA, Przyklenk K, Whittaker P. Deleterious effects of oxygen radicals in ischemia/reperfusion. Resolved and unresolved issues. Circulation 1989; 80: 1115-27. (doi: 10.1161/01.CIR.80.5.1115).
23. Opie LH. Reperfusion injury and its pharmacologic modification. Circulation. 1989; 80: 1049-62. (doi: 10.1161/01.CIR.80.4.1049).

24. Bal C, Buyuksekerci M, Koca C, Agıs ER, Erdogan S, et al. The compromise of dynamic disulfide/thiol homeostasis as a biomarker of oxidative stres in trichloroethylene exposure. Hum Exp Toxicol. 2015; 49: 1-6.

25. Erel O. A new automated colorimetric method for measuring total oxidant status. Clinical Biochemistry. 2005; 9: 1-9. (doi: 10.1016/j.clinbiochem.2005.08.008).

26. Elmas $B$, Karacan $M$, Dervişoğlu $P$, Kösecik $M$, İşgüven ŞP, Bal C. Dynamic thiol/disulphide homeostasis as a novel indicator of oxidative stress in obese children and its relationship with inflammatory-cardiovascular markers. Anatol J Cardiol. 2017;18(5): 361-9. (doi: 10.14744/ AnatolJCardiol.2017.7740).

27. Ates I, Kaplan M, Inan B, Alisik M, Erel O, Yilmaz N, et al. How does thiol/disulfide homeostasis change in prediabetic patients? Diabetes Res Clin Pract. 2015; 110(2): 166-71. (doi: 10.1016/j.diabres.2015.09.011).

28. Ates I, Ozkayar N, Inan B, Yilmaz FM, Topcuoglu C, Neselioglu $S$, et al. Dynamic thiol/disulphide homeostasis in patients with newly diagnosed primary hypertension. J Am Soc Hypertens. 2016; 10(2): 159-66. (doi: 10.1016/j.jash.2015.12.008).

29. Erkenekli K, Sanhal CY, Yucel A, Bicer CK, Erel O, Uygur D. Thiol/disulfide homeostasis in patients with idiopathic recurrent pregnancy loss assessed by a novel assay: Report of a preliminary study. J Obstet Gynaecol Res. 2016; 42(2): 136-41. (doi: 10.1111/jog.12860).

30. Matteucci E, Giampietro O. Thiol signalling network with an eye to diabetes. Molecules. 2010; 15: 8890-903. (doi: 10.3390/molecules15128890).

31. Senyurt M, Neselioglu S, Bicer CK, Yildiz F, Gözcü $H$, Carlıoglu A. Decreased Thiol Levels, Increased Disulphide Levels Are Associated with Increased Blood Glucose Levels in Newly Diagnosed Type 2 Diabetes. West Indian Medical Journal.

32. Kundi $H$, Erel Ö, Balun A, Çiçekçioglu $H$, Cetin M, Kiziltunç $E$, et al. Association of thiol/disulfide ratio with syntax score in patients with NSTEMI. Scand Cardiovasc J. 2015; 49(2): 95-100. (doi: 10.3109/14017431.2015.1013153). 
33. Eren Y, Dirik E, Neselioglu S, Erel Ö. Oxidative stress and decreased thiol level in patients with migraine: Crosssectional study. Acta Neurol Belg. 2015; 115(4): 643-9. (doi: 10.1007/s13760-015-0427-y).

34. Erkus ME, Altiparmak IH, Akyuz AR, Demirbag R, Sezen $Y$, Gunebakmaz $\mathrm{O}$, et al. The association between plasma thiol levels and left ventricular diastolic dysfunction in patient with hypertension. Scand J Clin Lab Invest. 2015; 75(8): 667-73. (doi: 10.1016/j.amjcard.2015.01.076).

35. Kaya S, Sütçü R, Çetin ES, Nigar Yılmaz N, Arıkan S, Arıdoğan BC, Delibaş N. Relationship Between Viral Load and Lipid Peroxidation and Antioxidant Enzymes in Patients Infected with Hepatitis B Virus. Türk Klinik Biyokimya Derg 2006; 4(2): 77-82.
36. Wang K, Wang B, Fan XP, Lin YJ, Shui WP. Oxidative stress in patients with chronic hepatitis B. Zhonghua Shi Yan He Lin Chuang Bing Du Xue Za Zhi 2004; 18: 172-4.

37. Schmilovitz-Weiss H, Tovar A, Halpern M., Sulkes J, Braun $M$, Rotman $Y$. et al. Predictive value of serum globulin levels for the extent of hepatic fibrosis in patients with chronic hepatitis B infection. J Viral Hepat 2006; 13: 6717. (doi: 10.1111/j.1365-2893.2006.00744.x).

38. Kandemır Ö, Bayarslan C, Kaya A. Isolated Anti-Hbc positive subjects and their response to Hepatitis $B$ vaccine. Viral Hepatit Derg 2002; (1): 430-1. 